\title{
Effect of enhanced external counterpulsation therapy on myeloperoxidase in lowering cardiovascular events of patients with chronic heart failure
}

\author{
Starry H. Rampengan, ${ }^{1}$ Budhi Setianto, ${ }^{2}$ Jimmy Posangi, ${ }^{3}$ Suzanna Immanuel, ${ }^{4}$ Judo Prihartono, ${ }^{5}$ Minarma Siagian, ${ }^{6}$ \\ Harmani Kalim, ${ }^{2}$ Sirowanto Inneke, ${ }^{7}$ Murdani Abdullah, ${ }^{8}$ Sarwono Waspadji, ${ }^{8}$ \\ ${ }^{1}$ Departement of Cardiology and Vascular Medicine, Faculty of Medicine, University Sam Ratulangi, Manado, Indonesia \\ ${ }^{2}$ Departement of Cardiology and Vascular Medicine, Faculty of Medicine, Universitas Indonesia, Jakarta, Indonesia \\ ${ }^{3}$ Departement of Pharmacology, Faculty of Medicine, University Sam Ratulangi, Manado, Indonesia \\ ${ }^{4}$ Departement of Clinical Pathology, Faculty of Medicine, Universitas Indonesia, Jakarta, Indonesia \\ ${ }^{5}$ Departement of Community Medicine, Faculty of Medicine, Universitas Indonesia, Jakarta, Indonesia \\ ${ }^{6}$ Departement of Physiology, Faculty of Medicine, Universitas Indonesia, Jakarta, Indonesia \\ ${ }^{7}$ Departement of Obstetric and Gynecology, Awal Bros Hospital, Tangerang, Indonesia \\ ${ }^{8}$ Departementof Internal Medicine, Faculty of Medicine, Universitas Indonesia, Jakarta, Indonesia
}

\begin{abstract}
Abstrak
Latar belakang: Gagal jantung kronik merupakan penyakit progresif lambat dengan morbiditas serta mortalitas yang tinggi; penggunaan obat-obatan seringkali tidak berhasil memperbaiki hasil keluaran. Enhanced external counterpulsation (EECP) bersifat non-invasive dan merupakan alternatif terapi dalam penanganan gagal jantung. Penelitian ini bertujuan menilai pengaruh EECP terhadap myeloperoksidase (MPO) sebagai penanda inflamasi, dan pada keluaran klinis.
\end{abstract}

Metode: Penelitian ini menggunakan desain uji klinik terkontrol secara randomisasi terbuka terhadap 66 penderita gagal jantung kronik pada Januari-Desember 2012. Pasien dibagi dalam dua kelompok: kelompok yang menjalani terapi EECP $(n=33)$ dan yang tidak menjalani terapi (non-EECP) $(n=33)$. Pemeriksaan MPO dilakukan pada awal dan setelah 6 bulan pengamatan. Selain itu juga dinilai kejadian kardiovaskular. Uji t tidak berpasangan digunakan untuk membandingkan kadar MPO dan uji chi-kuadrat untuk analisis kejadian kardiovaskular.

Hasil: Pengukuran kadar MPO awal dan setelah 6 bulan pengamatan pada kelompok EECP dan non-EECP berturutturut: $643,16 \pm 239,40$ dan 422,31 $\pm 156,26 \mathrm{pM}(\mathrm{p}<0,001)$ tetapi pada kelompok non-EECP $(584,69 \pm 281,40 \mathrm{pM}$ menjadi 517,64 $\pm 189,68$ pM) secara statistik tidak bermakna $(p=0,792)$. Penurunan kadar MPO sangat bermakna secara statistik pada semua pasien kelompok EECP dibandingkan kelompok non-EECP (13 pasien). Hasil perhitungan risiko relatif (RR) menyatakan bahwa dampak penurunan MPO pada kelompok EECP 2,08 kali lebih baik daripada kelompok non-EECP. Pengamatan kejadian kardiovaskular setelah 6 bulan penelitian menunjukkan perbedaan bermakna antara kedua kelompok ( $p=0,037)$. Kejadian kardiovaskular kelompok non-EECP ditemukan 15 pasien (45,5\%) sedangkan pada kelompok EECP hanya ditemukan 7 pasien $(21,2 \%)$.

Kesimpulan: Terapi EECP menurunkan kadar MPO pasien GJK sehingga dapat menurunkan kejadian kardiovaskular dalam 6 bulan pengamatan. Makin tinggi kadar MPO berkorelasi dengan makin tingginya insiden kejadian kardiovaskular. (Med J Indones. 2013;22:152-60. doi: 10.13181/mji.v22i3.584)

\begin{abstract}
Background: Chronic heart failure (CHF) is a slowly progressive disease with high morbidity and mortality; therefore, the management using pharmacological treatments frequently fails to improve outcome. Enhanced external counterpulsation (EECP), a non-invasive treatment, may serve as alternative treatment for heart failure. This study was aimed to evaluate the influence of EECP on myeloperoxidase (MPO) as inflammatory marker as well as cardiac events outcome.

Methods: This was an open randomized controlled clinical trial on 66 CHF patients visiting several cardiovascular clinics in Manado between January-December 2012. The subjects were randomly divided into two groups, i.e. the group who receive EECP therapy and those who did not receive EECP therapy with 33 patients in each group. Myeloperoxidase (MPO) as inflammatory marker was examined at baseline and after 6 months of observation. Cardiovascular events were observed as well after 6 months of observation. Unpaired t-test was use to analyze the difference of MPO between the two groups, and chi-square followed by calculation of relative risk were used for estimation of cardiovascular event outcomes.

Results: MPO measurement at baseline and after 6 months in EECP group were $643.16 \pm 239.40 \mathrm{pM}$ and $422.31 \pm$ $156.26 \mathrm{pM}$, respectively $(\mathrm{p}<0.001)$. Whereas in non EECP group, the MPO values were $584.69 \pm 281.40 \mathrm{pM}$ and 517.64 $\pm 189.68 \mathrm{pM}$, repectively $(\mathrm{p}=0.792)$. MPO reduction was observed in all patients of EECP group and in 13 patients $(48 \%)$ of non-EECP group $(\mathrm{p}<0.001)$. Cardiovascular events were observed in $7(21.21 \%)$ and $15(45.45 \%)$ of patients in EECP and non-EECP groups, respectively $(\mathrm{p}=0.037)$.

Conclusion: EECP therapy significantly decreased the level of MPO as inflammatory marker and this decrease was correlated with the reduction of cardiovascular events in CHF patients. (Med J Indones. 2013;22:152-60. doi: 10.13181/mji.v22i3.584)
\end{abstract}

Keywords: $C H F$, cardiovascular events, EECP, myeloperoxidase 
Chronic heart failure (CHF) is a slowly progressive disease, therefore it is difficult to lower mortality and morbidity due to high cardiovascular events. ${ }^{1}$ Hospital readmission rate of CHF in one month is approximately $20 \%$ and almost $50 \%$ in six months. ${ }^{2,3}$ Inflammation may have important roles in CHF pathophysiological mechanism. ${ }^{4}$

Increased oxidative stress and endothelial dysfunction are commonly observed in patients with CHF. The relation between myeloperoxidase (MPO), an inflammatory marker with mechanistic links to plaque vulnerability and abnormal ventricular remodeling, and degrees of severity in chronic HF has been rarely reported. ${ }^{5}$ Myeloperoxidase as a recent inflammatory marker has been found increasing in patients with $\mathrm{CHF}^{4-6}$ Elevated MPO levels in CHF are associated with the progressivity and severity of disease and predictive of high cardiovascular events. ${ }^{7,8}$

Heart failure management available is not only pharmacological, but also non-invasive using enhanced external counterpulsation (EECP) for patients who are resistant to pharmacological or invasive treatment. ${ }^{7,8}$ EECP is a non-invasive pneumatic technique that utilizes rapid electrocardiogram-gated sequential inflation of cuffs wrapped around the calves, thighs, and buttocks at supra-systolic pressures during diastole, followed by simultaneous deflation during systole. On diastole, cuffs inflate sequentially from the calves, raising diastolic aortic pressure proximally and increasing coronary perfusion pressure. Compression of the vascular beds of the legs also increases venous return. Instantaneous decompression of all cuffs at the onset of systole significantly unloads the left ventricle, thereby lowering vascular impedance and decreasing ventricular workload. This latter effect, when coupled with augmented venous return, raises cardiac output. In summary, EECP increases venous return, raises cardiac preload, increases cardiac output, and decreases systemic vascular resistance. ${ }^{9}$

EECP therapy still retained IIb class of recommendation (COR) rating and given a $\mathrm{B}$ rating for level of evidence (LOE) in the ACC/AHA 2012 guideline for the diagnosis and management of patients with stable ischemic heart disease. In the management of heart failure, EECP is still not included in the guideline because it still does not have strong evidence that provide more definitive data on how well EECP might benefit patients with heart failure. ${ }^{10}$

In brief, the mechanism of action of EECP in heart failure includes reducing afterload, improve contractility and reducing myocardial oxygen demand.
Increased coronary blood flow by EECP will promote myocardial collateralization through the formation of collateral vessels, arteriogenesis, and angiogenesis. Increased blood flow and shear stress endothel (SSE) will improve coronary endothelial function, vasodilatation and myocardial perfusion. ${ }^{9,10}$

This study was aimed to identify the effectiveness as well as the correlation between EECP treatment and MPO levels in lowering cardiovascular events for CHF patients in six months observation period.

\section{METHODS}

Consecutive sampling was performed and the samples were patients with CHF who visited Outpatient Cardiology Unit at General Hospital of Prof Dr. R. D. Kandou, Manado Siloam Hospital, Manado Adventist Hospital and Manado Jade Cardiovascular Clinic and those who were recruited during free visit to rural areas in Manado, North Sulawesi who fulfilled inclusion criteria. The inclusion criteria were age of 25-79 years, patients with symptomatic chronic heart failure who had mild to moderate symptoms or class II-III according to New York Heart Association (NYHA) category with etiology of ischemic heart disease, hypertensive heart disease, coronary heart disease or acute coronary syndrome; ejection fraction $<40 \%$, patients with $\mathrm{CHF}$ who had received standard treatment in keeping with the national guidelines of heart failure management at least one months prior to the study, and willing to participate in the study and signed informed consent form. All samples were randomized into intervention and control group. Block randomization was used for both groups. The protocol of this study has been approved by the Ethics Committee of Kandou Hospitals/ Faculty of Medicine, Sam Ratulangi University with letter number 014.04.01/11.2/575/2012.

The study was conducted between Januari 2012 and December 2012. There were 33 subjects who had EECP treatment and 33 subjects without EECP treatment (non-EECP) enrolled in this study. The subjects in EECP treatment group (intervention group) would receive routine treatment of EECP every day for one hour up to 35 times; while the subjects in nonEECP group would only receive standard management of heart failure according to the standard treatment at Harapan Kita National Cardiology Center.

All subjects in both groups had undergone history taking, physical examination, ECG, Chest X-Ray, and echocardiography to evaluate ejection fraction and blood sampling had also been done at the beginning of study. The major adverse cardiovascular events 
included ischemic stroke, all-cause mortality and re-hospitalization were observed in the both groups for six months. After six months observation period, both groups were being re-evaluated with equal examinations performed initially.

Data was collected and documented using Microsoft Excel. Statistical analysis was performed using SPSS.inc version 11.5. The analyzed variables were history taking, clinical examination, ECG, echocardiography, chest X-ray and the 6-month observed laboratory results that were relevant to cardiovascular events. The analysis included univariate analysis using t-test and chi-square. Results with $\mathrm{p}<0.05$ were considered statistically significant. Interpretation of results was performed by intent to treat approach. All variables that had $\mathrm{p}<$ 0.25 were included in multivariate analysis to obtain relative risk and relative risk reduction. Survival analysis for mortality rate was performed using Kaplan Meier and Hazard Ratio Cox Proportional.

\section{RESULTS}

A total of 66 patients have participated in our study, which consisted of 50 male patients $(75.8 \%)$ and 16 female patients $(24.2 \%)$ with average age of $61.3 \pm$ 10.6 years. There were 24 male $(72.7 \%)$ and 9 female subjects $(27.3 \%)$ in EECP group; while in the nonEECP group, there were 26 male $(78.8 \%)$ and 7 female $(21.2 \%)$ subjects. It can be seen that both groups were comparables in term of demographic data (Table 1) and baseline laboratory, echocardiography, and chest X-ray (Table 2).

MPO level was measured on 32 patients of EECP group and 27 patients of non-EECP group. Of 32 subjects in EECP group, the baseline MPO was $643.16 \pm 239.40 \mathrm{pM}$ and significantly decreased to $422.31 \pm 156.26 \mathrm{pM}$ at 6 months observation $(\mathrm{p}<$ 0.001 ). In non-EECP group, there was a reduction of MPO levels from $584.69 \pm 281.40 \mathrm{pM}$ to 517.64 $\pm 189.68 \mathrm{pM}$. The difference was not statistically significant $(\mathrm{p}=0.792)($ Table 3$)$.

The results show that there were statistically significant reductions of MPO levels in all subjects of EECP group but only in 13 patients of non-EECP group. Evaluation on relative risk (RR) for MPO reductions showed that there were 2.08 lower risks in EECP group than nonEECP group (Table 4).

Observation on cardiovascular events after six months of study showed significant difference between both groups $(p=0.037)$. Cardiovascular events in non-
Table 1. Baseline subject characteristics of EECP and non-EECP group (Demography, NYHA class, CHF Severity, comorbidity, and medication)

\begin{tabular}{|c|c|c|}
\hline \multirow[b]{2}{*}{ Variabels } & \multicolumn{2}{|c|}{ Group } \\
\hline & $\begin{array}{c}\text { EECP } \\
(n=33)\end{array}$ & $\begin{array}{c}\text { Non-EECP } \\
(\mathrm{n}=33)\end{array}$ \\
\hline \multicolumn{3}{|l|}{ Demography } \\
\hline \multicolumn{3}{|l|}{ Sex } \\
\hline Male & $24(72.7 \%)$ & $26(78.8 \%)$ \\
\hline Age (years) & $60.3 \pm 9.3$ & $62.3 \pm 12.0$ \\
\hline \multicolumn{3}{|l|}{ NYHA classification } \\
\hline Class I & $0(0 \%)$ & $0(0 \%)$ \\
\hline Class II & $24(72.72 \%)$ & $23(69.69 \%)$ \\
\hline Class III & $9(27.27 \%)$ & $10(30.30 \%)$ \\
\hline Class IV & $0(0 \%)$ & $0(0 \%)$ \\
\hline \multicolumn{3}{|l|}{ CHF severity } \\
\hline Level B & $6(15.2 \%)$ & $8(24.2 \%)$ \\
\hline Level C & $28(84.8 \%)$ & $25(75.8 \%)$ \\
\hline \multicolumn{3}{|l|}{ Comorbidities } \\
\hline Hypertension & $24(72.7 \%)$ & $23(69.7 \%)$ \\
\hline Diabetes Mellitus & $10(30.3 \%)$ & $9(27.3 \%)$ \\
\hline Dyslipidemia & $23(69.7 \%)$ & $23(69.7 \%)$ \\
\hline \multicolumn{3}{|l|}{ Medication } \\
\hline ACE Inhibitor/ARB & $33(100 \%)$ & $32(97 \%)$ \\
\hline Beta blocker & $24(72.7 \%)$ & $25(75.8 \%)$ \\
\hline Diuretic & $21(63.6 \%)$ & $24(72.7 \%)$ \\
\hline Spironolactone & $20(60.6 \%)$ & $19(57.6 \%)$ \\
\hline Nitrate & $17(51.5 \%)$ & $20(60.6 \%)$ \\
\hline Digoxin & $15(45.5 \%)$ & $13(39.4 \%)$ \\
\hline Statin & $22(66.6 \%)$ & $23(69.7 \%)$ \\
\hline
\end{tabular}

EECP were found in 15 patients $(45.4 \%)$; while there were only 7 patients (21.2\%) in EECP group (Table 5).

Figure 1 showed several cardiovascular events in both study groups. In EECP group, seven patients had cardiovascular events including one patient who died at home, one patient had ischemic stroke and five patients were readmitted to hospital. Patients who had been readmitted to hospital in EECP group comprised of one anemic patient who required blood transfusion, one patient with total $\mathrm{AV}$ block and required installation of a permanent pace maker, and three patients were readmitted due to dyspnea induced by lung infection. 
Table 2. Baseline subject characteristics of EECP and non-EECP group (Laboratory, echocardiography and roentgen)

\begin{tabular}{|c|c|c|}
\hline \multirow[b]{2}{*}{ Variabel } & \multicolumn{2}{|c|}{ Group } \\
\hline & $\begin{array}{c}\text { EECP } \\
(\mathrm{n}=33)\end{array}$ & $\begin{array}{l}\text { Non-EECP } \\
(\mathrm{n}=33)\end{array}$ \\
\hline \multicolumn{3}{|l|}{ Laboratory } \\
\hline Hemoglobin (g/dL) & $13.6 \pm 1.8$ & $12.7 \pm 2.3$ \\
\hline Leukocyte $\left(10^{3} / \mathrm{mL}\right)$ & $7.9 \pm 1.9$ & $7.7 \pm 2.2$ \\
\hline BNP (pg/mL) & $573.0 \pm 385.3$ & $554.5 \pm 308.9$ \\
\hline Blood urea (mg/dL) & $45.76 \pm 31.75$ & $48.69 \pm 29.75$ \\
\hline Creatinin $(\mathrm{mg} / \mathrm{dL})$ & $1.37 \pm 0.43$ & $1.57 \pm 0.77$ \\
\hline Uric acid $(\mathrm{mg} / \mathrm{dL})$ & $8.2 \pm 2.1$ & $7.7 \pm 2.1$ \\
\hline Fasting blood glucose (mg/dL) & $93.9 \pm 30.3$ & $110.4 \pm 45.1$ \\
\hline 2 hrs Post-prandial blood glucose (mg/dL) & $134.7 \pm 42.7$ & $142.2 \pm 51.4$ \\
\hline HbA1c (\%) & $6.6 \pm 1.3$ & $6.8 \pm 1.7$ \\
\hline Total cholesterol (mg/dL) & $209.2 \pm 49.7$ & $214.0 \pm 69.2$ \\
\hline HDL cholesterol (mg/dL) & $38.3 \pm 8.7$ & $33.4 \pm 8.7$ \\
\hline LDL cholesterol (mg/dL) & $153.8 \pm 49.9$ & $156.8 \pm 33.5$ \\
\hline Triglyceride (mg/dL) & $139.7 \pm 83.9$ & $131.2 \pm 78.4$ \\
\hline SGOT (U/L) & $34.21 \pm 15.11$ & $32.52 \pm 2.52$ \\
\hline SGPT (U/L) & $40.30 \pm 20.79$ & $32.76 \pm 15.70$ \\
\hline \multicolumn{3}{|l|}{ Echocardiography } \\
\hline Ejection fraction (\%) & $31.4 \pm 4$ & $32.1 \pm 4.1$ \\
\hline LVEDD (mm) & $63.3 \pm 8.2$ & $60.9 \pm 9.5$ \\
\hline LVESD (mm) & $51.8 \pm 7.7$ & $49.6 \pm 8.8$ \\
\hline Right ventricular function (mm) & $18.4 \pm 5.1$ & $18.4 \pm 5.8$ \\
\hline \multicolumn{3}{|l|}{ Roentgen } \\
\hline $\mathrm{CTR} \leq 50 \%$ & $10(30.3 \%)$ & $13(39.9 \%)$ \\
\hline CTR $60-70 \%$ & $16(48.8 \%)$ & $14(42.4 \%)$ \\
\hline $\mathrm{CTR}>70 \%$ & $7(21.9 \%)$ & $6(18.2 \%)$ \\
\hline
\end{tabular}

Cardiovascular events in non-EECP group consisted of six deaths, one ischemic stroke and eight readmissions to hospital. Among those who had been readmitted to hospital, two patients were anemic and required blood transfusion, two patients were due to fatigue, four patients were due to dyspnea (two cases had been induced by fluid overload and two cases by lung infection). Of six deaths occurred in non-EECP group, three were caused by sudden cardiac arrest, one was due to gastric bleeding, and two cases were due to severe dyspnea.

Survival analysis based on observation days for cardiovascular events (Figure 2) found seven patients
(21.2\%) in EECP group and 15 patients $(45.5 \%)$ in non-EECP group had cardiovascular events, with statistically significant difference $(p<0.05)$. The difference was obvious on observation day 79 .

\section{DISCUSSION}

Based on sample characteristic distribution, our study demonstrated that heart failure was predominantly found in male compared to female patients, i.e. 50 patients $(75.8 \%)$, with average age of patients with chronic heart failure was $61.3 \pm 10.6$ years. This finding is similar to United States NHLBI (National 
Table 3. Comparison of baseline MPO level and six-month MPO levels in EECP group and non-EECP group

\begin{tabular}{lccc}
\hline \multirow{2}{*}{ Groups } & Baseline MPO level $(\mathrm{pM})$ & Six-month MPO level $(\mathrm{pM})$ & $\mathrm{p}$ \\
\cline { 2 - 3 } & Mean \pm SD & Mean \pm SD & \\
\hline EECP $(\mathrm{n}=32)$ & $643.16 \pm 239.40$ & $422.31 \pm 156.26$ & $<0.001$ \\
Non-EECP $(\mathrm{n}=27)$ & $584.69 \pm 281.40$ & $517.64 \pm 189.68$ & 0.110 \\
\hline
\end{tabular}

Statistical analysis using paired t-test

Table 4. Subjects distribution based on MPO changes and groups

\begin{tabular}{lccccc}
\hline & \multicolumn{2}{c}{ MPO changes } & & \\
\cline { 2 - 3 } & $\begin{array}{c}\text { Reduced } \\
\mathrm{n}(\%)\end{array}$ & $\begin{array}{c}\text { Elevated } \\
\mathrm{n}(\%)\end{array}$ & $\mathrm{n}$ & $\mathrm{p}$ \\
\hline EECP & $32(100)$ & $0(0)$ & 32 & $<0.001$ \\
Non-EECP & $13(48.15)$ & $14(51.85)$ & & 27 & \\
Total & 45 & 14 & 59 & \\
\hline
\end{tabular}

Comparison test between both groups using chi-square; RR $=2.08$ (95\% CI 1.40-3.07)

Table 5. Cardiovascular events at the end of observation in EECP and non-EECP group

\begin{tabular}{|c|c|c|c|c|}
\hline \multirow[b]{2}{*}{ Group } & \multicolumn{2}{|c|}{ Cardiovascular events } & \multirow[b]{2}{*}{$\mathrm{n}$} & \multirow[b]{2}{*}{$\mathrm{p}$} \\
\hline & $\begin{array}{c}\text { Positive } \\
\text { n (\%) }\end{array}$ & $\begin{array}{c}\text { Negative } \\
\mathrm{n}(\%)\end{array}$ & & \\
\hline EECP & $7(21.21)$ & $26(78.78)$ & 33 & \\
\hline Non-EECP & $15(45.45)$ & $18(54.54)$ & 33 & 0.037 \\
\hline Total & 22 & 44 & 66 & \\
\hline
\end{tabular}

Comparison test between both groups using chi-square $\mathrm{RR}=0.47$; (95\% CI 0.22-0.99)

Heart Lung and Blood Institute) data in 2009, which reported that chronic heart failure prevalence is higher in male patients with advancing age. ${ }^{11}$ Comorbidities were found in both groups, mostly were hypertension and dyslipidemia. Hypertension is one of the common comorbidities in CHF as it increases cardiac load and causes left ventricle hypertrophy, worsens the systolic heart failure. Manickavasagam, et al ${ }^{12}$ reported hypertension as the most common comorbidities (75\%) in CHF patients. ${ }^{12}$ Our subjects were all from Minahasa ethnic group where hypertension and dyslipidemia are frequently found and may be associated with high saturated fat diet and alcoholic beverages intake. ${ }^{13}$ In addition to hypertension and dyslipidemia, hyperuricemia was also a common comorbidity in our subjects.

In chronic heart failure, vascular shear stress is reduced persistently; thus, it worsens endothelial dysfunction.
Our study is the first to find that EECP can reduce MPO level in CHF patients. This might be due to the effect of chronic pulsatile, which was developed during treatment. Significant reduction was observed in EECP compared to the non-EECP group. Enhanced external counterpulsation will trigger pulsatile blood flow; thus, increasing endothelial shear stress (ESS) which will improve endothelial function, induces increased level of anti-inflammatory marker and reduces pro-inflammation cytokine, reduces macrophage accumulation and complement activation as well as reduces vascular inflammation. Pulsatile blood flow generated by EECP is proven to be effective in reducing monocyte adhesion to endothelial cells, excretes oxLDL and induces endothelial nitric oxide synthase (eNOS) to produce nitric oxide (NO)..$^{14-17}$

Physiologically, pulsatile ESS is a potent stimulus to endothelial to produce NO continuously. ${ }^{18}$ Nitric oxide 


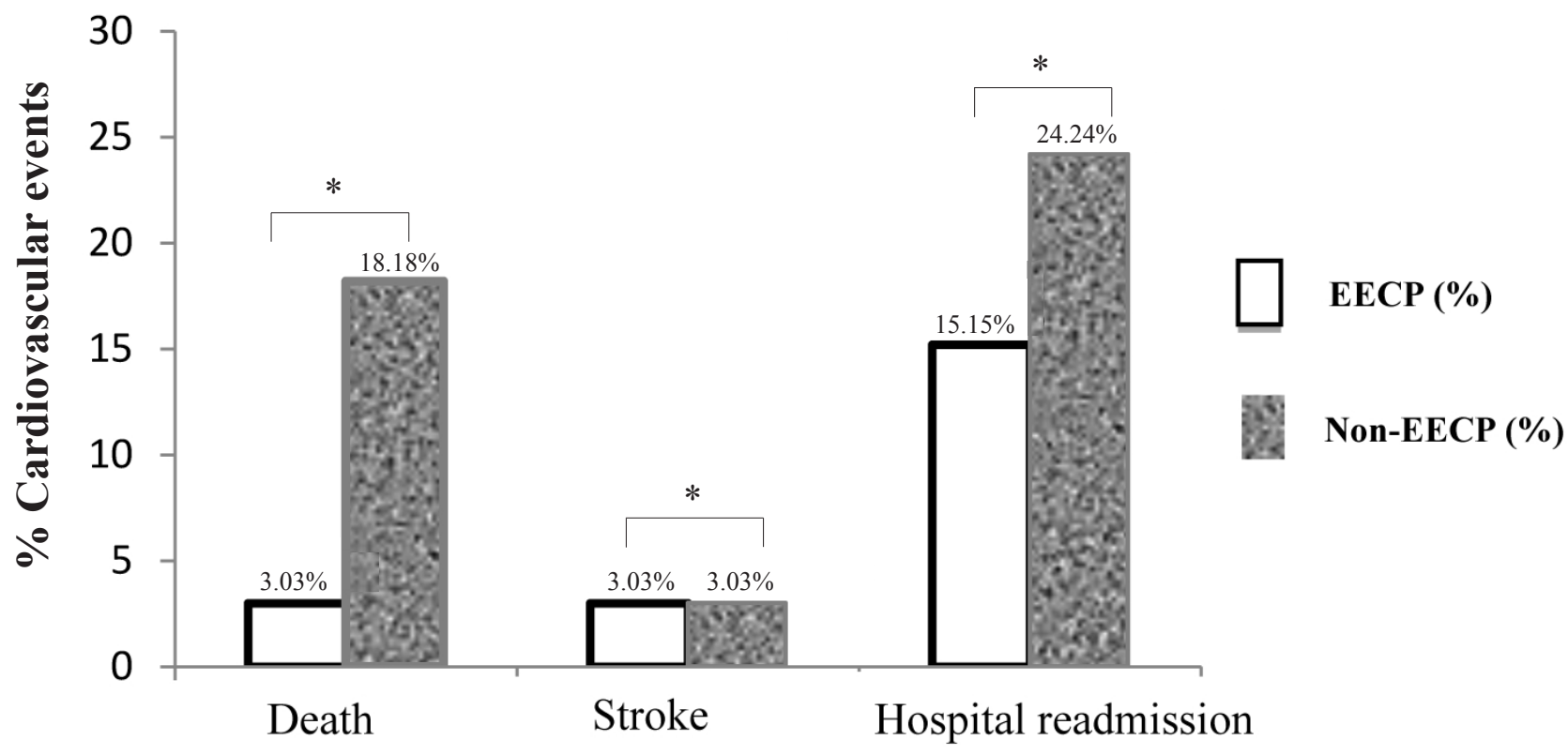

Figure 1. Cardiovascular events types and percentage in EECP and non-EECP group ${ }^{*} p>0.05$

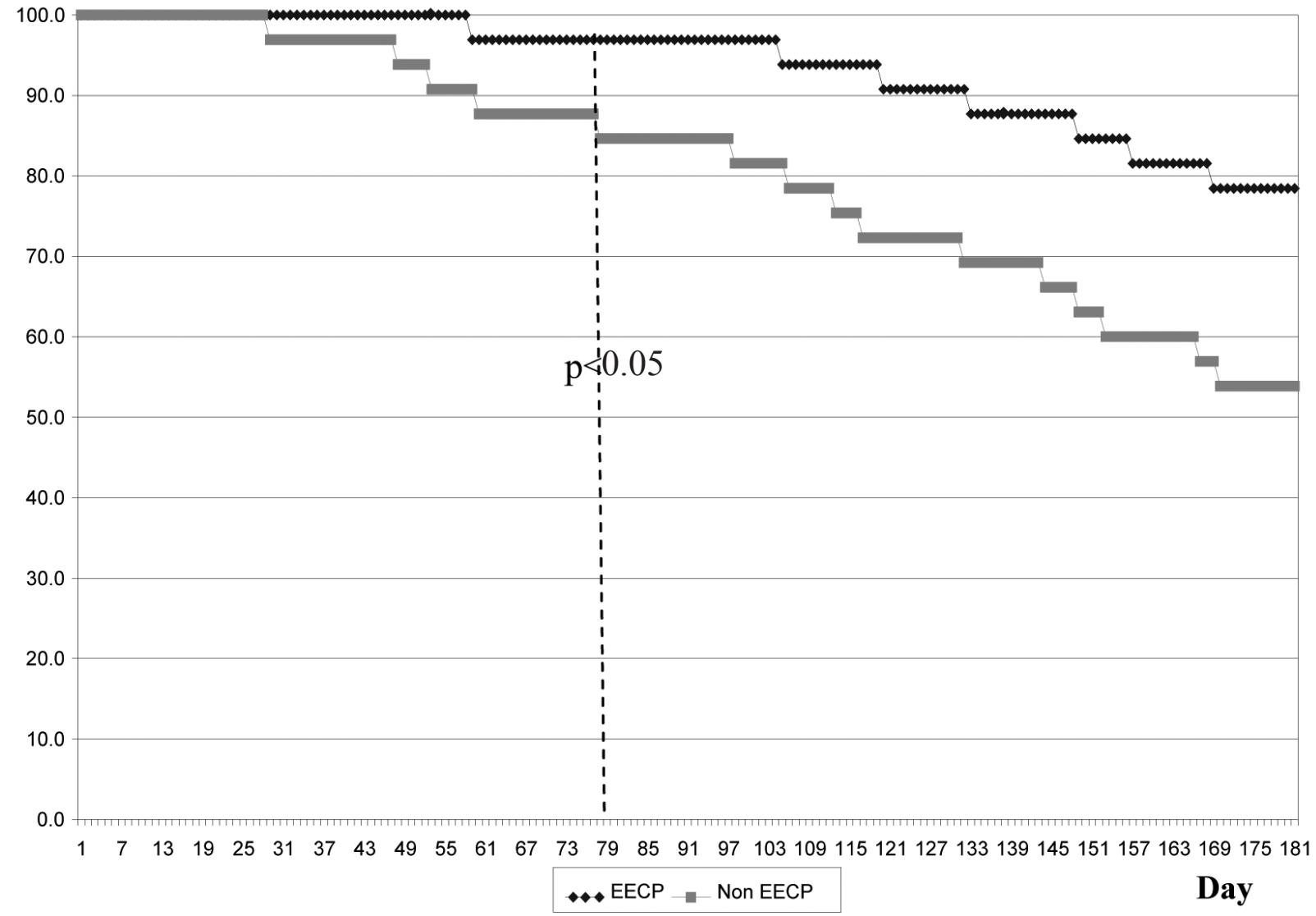

Figure 2. Survival analysis for cardiovascular events in EECP and non-EECP group

has important role in improving myocardial metabolism and contractility in heart failure. ${ }^{19}$ The higher NO production generated by EECP pulsatile effects, the lesser unpaired eNOS will be produced; therefore, peroxide acid $\left(\mathrm{H}_{2} \mathrm{O}_{2}\right)$ formation were reduced, which will react with MPO to form hipochloride acid (HOCL), which is a key element for endothelial cell apoptosis and adhesion molecule expression. ${ }^{20}$ 
Table 6. MPO level based on cardiovascular events in EECP group

\begin{tabular}{lccr}
\hline \multirow{2}{*}{$\begin{array}{c}\text { Variables } \\
\text { MPO }(\mathrm{pM})\end{array}$} & $\begin{array}{c}\text { No cardiovascular events } \\
(\mathrm{n}=26)\end{array}$ & $\begin{array}{c}\text { Cardiovascular events } \\
(\mathrm{n}=7)\end{array}$ & \multirow{2}{*}{$\mathrm{p}$} \\
\cline { 2 - 3 } & Average $\pm \mathrm{SD}$ & Average $\pm \mathrm{SD}$ & \\
\hline Baseline MPO & $666.97 \pm 176.97$ & $1084.34 \pm 179.34$ & $<0.001^{*}$ \\
Post MPO treatment & $394.85 \pm 88.68$ & $378.16 \pm 67.59$ & 0.324 \\
End MPO & $477.88 \pm 104.13$ & $714.85 \pm 205.95$ & $<0.001^{*}$ \\
Changes & $189.09 \pm 153.33$ & $369.49 \pm 222.60$ & $0.016^{*}$ \\
\hline
\end{tabular}

Statistic test using unpaired t-test

$* \mathrm{p}<0.05$ was statistically significant

Note: changes $=$ differences between baseline MPO and MPO levels at the end of observation

This study produced significant improvement of fraction ejection in EECP group rather than non-EECP (data not shown). This is probably due to EECP therapy that could decrease systolic blood pressure and increase diastolic blood pressure leading to decreased vascular systemic resistance and after load and increased cardiac output that subsequently improve the function of left ventricle and decrease heart rate. EECP has significant increase of $\mathrm{NO}$ release that activates guanylcyclase receptor which in turn stimulates cyclic guanosine monophosphate (cGMP) accumulation on vascular smooth muscle tone. Increased of cGMP regulates vascular smooth muscle tone, endothelial permeability and fibroblast growth and differentiation as well resulting in improved myocardial function..$^{19,20}$

The quality of life and functional capacity in EECP group were found significantly improved in posttherapy but not in non-EECP (data not exposed). The viewpoints of several investigators agreed that the hemodynamic effects of EECP could improve myocardial perfusion through stimulations of growth of blood vessel in intra myocardial and coroner perfusion, combined with modification during therapy could increase physical capability and improve the quality of life. The improvement of functional capacity after EECP has been related to peak oxygen uptake by increasing perfusion pressure during therapy which might improve oxygen supply and promote the recovery of otherwise non-functional areas of the myocardium. Other effect has been produced by an increase of nitric oxidase with subsequent coronary and systemic vasodilatation. ${ }^{10,12,21}$

Reduction of MPO level in EECP group was correlated to reduction of cardiovascular events. In this study we found that the relative risk (RR) was 0.47 , which means EECP can prevent cardiovascular events of two-fold better compared to non-EECP group. The effects of EECP treatment in lowering cardiovascular events are reduced cardiovascular events through improvement of endothelial morphology and function, reduced inflammation and oxidative stress and promoted angiogenesis and vasculogenesis. Reduced MPO level was associated with improvement of endothelial function and tissue damage caused by increased EECPinduced shear stress which stimulates endothelial progenitor cells (EPCs). ${ }^{22,23}$

Endothelial progenitor cells are able to differentiate into new endothelial cells and associated with improved ventricle function following myocardial infarction, angiogenesis, and re-endothelization following vascular injuries. Reduction of MPO level will prevent apoptosis, both through extrinsic and intrinsic pathways; therefore, reducing myocardial cells dysfunction. Casey et al found that EECP promoted collateral blood vessels formation which was associated with systemic endothelial function. ${ }^{22,23}$

Mechanical shear stress will release stem cell from endothelial surface into the circulation; thus, it will replace old endothelial cells, repair damaged tissue and promote regeneration. These correlations were assumed to be the EECP long-term effects which are beneficial to cardiac function..$^{22,23}$

Significant reduction of cardiovascular events in EECP group was associated with reduced MPO level. A significant reduction of MPO level in EECP group will subsequently reduce amino acid oxidation and cytotoxic aldehyde production and will modify the cardiac ion channels. The effects of MPO in inhibiting PAI-1 activity would be also decreased. Therefore, plasmin activity would be reduced and resulting in extracellular matrix degradation; thus, ventricle remodeling and cardiac dilatation can be prevented. ${ }^{24,25}$ These were also important in reducing cardiovascular events in EECP group compared to non-EECP group.

Following the EECP treatment, there was a significant reduction in MPO levels, both in patients who had 
and had not had cardiovascular events. It suggests that the SSE pulsatile effect of EECP is very effective in reducing MPO. The MPO levels of subjects in EECP group who had cardiovascular events were compared between after treatment and at the end of observation and we found that there was increased MPO level with median of $326.60 \mathrm{pM}$ and it was statistically significant. Elevated MPO levels in subjects of EECP group who had cardiovascular events were caused by acute bacterial infection, i.e. pneumonia in three patients. Such condition increased pro-inflammatory cytokines and induced neutrophil PMN to release abundant MPO. Myeloperoxidase will up-regulate cytokine genes and activates alveolar macrophage; therefore, increasing inflammation and cytotoxic status, and worsening lung inflammation. ${ }^{26}$ Non-significant elevated level following the treatment compared to the end of the study was found among subjects who had no cardiovascular events, with median of $70.35 \mathrm{pM}$.

Our study concluded that EECP therapy can significantly reduce MPO level in $\mathrm{CHF}$ patients receiving therapy compared to control group. Several studies with bigger sample size and longer observation time are required to evaluate EECP therapeutic effects further in CHF patients. Further studies to prove the role of MPO as predictor of cardiovascular events in CHF are also necessary.

\section{Acknowledgment}

We would like to thank Miss Stevi Dungir and all Jade Cardiovascular Clinic staff (ns Bilfen, ns Richo, ns Surty, ns Icha, ns Dahlia, ns Gladly, ns Yanti, ns Gladys, ns Ayu, ns Irma, ns Lidya, Mrs Meivy, Miss Shally) for support during the research.

\section{REFERENCES}

1. Aukrust P, Gullestad L, Ueland T, Damås JK, Yndestad A. Inflamatory and anti inflamatory cytokine in chronic heart failure: potential therapeutic implication. Ann Med. 2005;37(2):74-85.

2. Ritzema J, Troughton R, Melton I, et al. Physiciandirected patient self-management of left atrial pressure in advanced chronic heart failure. Circulation. 2010;121(9):1086-95.

3. Giardiano A, Scalvini S, Zanelli E, et al. Multicenter randomised trial in home-based telemanagement to prevent hospital readmission of patients with chronic heart failure. Int J Cardiol. 2009;131(2):192-9.

4. Oikonomou E, Tousoulis D, Siasos G, Zaromitidou M, Papavassisiliou A, Stefanadis C. The role of inflammation in heart failure: new therapeutic approaches. Hellenic J Cardiol. 2011;52(1):30-40.

5. Tang WH, Brennan ML, Philip K, et al. Plasma myeloperoxidase levels in patients with chronic heart failure. Am J Cardiol. 2006;98(6):796-9.
6. Michowitz Y, Kisil S, Guzner-Gur H, et al. Usefulness of serum myeloperoxidase in prediction of mortality in patients with severe heart failure. IMAJ. 2008;10(12):884-8.

7. Andreou I, Tousoulis D, Miliou A, et al. Myeloperoxidase levels in patient with chronic heart failure: A randomized placebo-controlled study. Atherosclerosis. 2010;210(1):194-8.

8. Tang WH, Tong W, Troughton $\mathrm{R}$, et al. Prognostic value and echocardiographic determinants of plasma myeloproxidase levels in chronic heart failure. J Am Coll Cardiol. 2007;49(24):2364-70.

9. Yang DY, Wu GF. Vasculoprotective properties of enhanced external counterpulsation for coronary artery disease: beyond the hemodynamics. Int $\mathrm{J}$ Cardiol. 2013; 166(1):38-43.

10. Manchanda A, Soran O. Enhanced external counterpulsation and future directions - Step beyond medical management for patients with angina and heart failure. J Am Coll Cardiol. 2007;50(16):1523-31.

11. Nabel EG. Morbidity and mortality: 2009 chart book on cardiovascular, lung and blood disease. NHLBI.2009;38-42.

12. Manickavasagam $\mathrm{S}$, Merla $\mathrm{R}$, Koerner $\mathrm{MM}$, et al. Management of hypertension in chronic heart failure. Expert Rev Cardiovasc Ther. 2009;7(4):423-33.

13. Kandou DG. Kebiasaan makan makanan etnik Minahasa di provinsi Sulawesi Utara. Jurn Kes Mas. 2009;3(2):53-7. Indonesian.

14. Zhang Y, He X, Chen $\mathrm{X}$, et al. Enhanced external counterpulsation inhibits intimalhyperplasia by modifying shear stress responsive gene expression in hypercholesterolemicpigs. Circulation. 2007;116(5):526-34.

15. Abbottsmith CW, Chung ES, Varicchione T, et al. Enhanced external counterpulsation improves exercise duration and peak oxygen consumption in older patients with heart failure: a subgroup analysis of the PEECH trial. Congest Heart Fail. 2006;12(6):307-11.

16. Michaels AD, Tacy T, Teitel D, Shapiro M, Grossman W. Invasive left ventricular energetics during enhanced external counterpulsation. Am J Ther. 2009;16(3):239-46.

17. Zhang Y, He X, Liu D, et al. Enhanced external counterpulsation attenuates atherosclerosis progression through modulation of proinflammatory signal pathway. Arterioscler Thromb Vasc Biol. 2010;30(4):773-80.

18. Chatzizisis YS, Coskun AU, Jonas, Edelman ER, Feldman CL, Stone P. Role of endothelial shear stress in the natural history of coronary atherosclerosis and vascular remodeling: molecular, cellular, and vascular behavior. J Am Coll Cardiol. 2007;49(25):2379-93.

19. Tousoulis D, Papageorgiou N, Briasoulis A, et al. Conflicting effects of nitric oxide and oxidative stress in chronic heart failure:potential therapeutic strategies. Heart Fail Rev. 2012;17(1):65-79.

20. La Rocca G, Di Stefano A, Eleuteri E, et al. Oxidative stress induces myeloperoxidase expression in endocardial endothelial cells from patients with chronic heart failure. Basic Res Cardiol. 2009;104(3):307-20.

21. Soran O, Fleishman B, Demarco T, et al. Enhanced external counterpulsation in patients with heart failure: a multicenter feasibility study. Congest Heart Fail. 2002;8(4):204-8. 
22. Jewell WC, Houck DP, Watson LE, Dostal DE, Dehmer GJ. Enhanced external counterpulsation is a regenerative therapy. Front Biosci (Elite Ed). 2010;2:111-21.

23. Casey D, Conti R, Nichols W, Choi C, Khuddus M, Braith R. Effect of enhanced external counterpulsation on inflammatory cytokines and adhesion molecules in patients with angina pectoris and angiographic coronary artery disease. Am J Cardiol. 2008;101(3):300-2.

24. VasilyevN,Williams T, Brennan ML, etal.Myeloperoxidasegenerated oxidants modulate left ventricular remodeling but not infarct size after myocardial infarction. Circulation. 2005;112(18):2812-20.

25. Askari A, Brennan ML, Zhou X, et al. Myeloperoxidase and plasminogen activator inhibitor-1 play a central role in ventricular remodeling after myocardial infarction. J Exp Med. 2003; 197(5): 615-24.

26. Grattendick K, Stuart R, Roberts E, et al. Alveolar macrophage activation by myeloperoxidase: a model for exacerbation of lung inflammation. Am J Respir Cell Mol Biol. 2002;26(6):716-22. 